\title{
The economic impacts of climate change on the Chilean agricultural sector. A non-linear agricultural supply model
}

\author{
Roberto Ponce $^{1 *}$, Maria Blanco² ${ }^{2}$ and Carlo Giupponi ${ }^{3}$
}

\begin{abstract}
Agriculture could be one of the most vulnerable economic sectors to the impacts of climate change in the coming decades, with impacts threatening agricultural production in general and food security in particular. Within this context, climate change will impose a challenge to policy makers, especially in those countries that based their development on primary sectors. In this paper we present a non-linear agricultural supply model for the analysis of the economic impacts of changes in crop yields due to climate change. The model accounts for uncertainty through the use of Monte Carlo simulations about crop yields. According to our results, climate change impacts on the Chilean agricultural sector are widespread, with considerable distributional consequences across regions, and with fruits producers being worst-off than crops producers In general, the results reported here are consistent with those reported by previous studies showing large economic impacts on the northern zone. However, our model does not simulate remarkable economic consequences at the country level as previous studies did.
\end{abstract}

Key words: Climate change, farming model, irrigation, uncertainty.

\section{INTRODUCTION}

The agricultural sector could be one of the most vulnerable economic sectors to the impacts of climate change in the coming decades. Climate change impacts on crop production are related to changes in temperature and precipitation patterns, the frequency and magnitude of extreme weather events, and changes in seasonality and growing period, among others. All of these impacts may have consequences on agricultural production (Bates et al., 2008) and as a result, agricultural systems are forced to adapt to changing conditions. Climate Change Adaptation (CCA) thus emerges as a new field for scholars and practitioners at all levels, from local and autonomous adaptation strategies implemented by farmers, up to regional, national or global policies to orient planned adaptation.

Despite the relevance of public policies in coping with the climate change impacts, the inclusion of climate change adaptation as a new policy field is questioned

${ }^{1}$ Universidad del Desarrollo, Facultad de Economía y Negocios, Ainavillo 456, Concepción, Chile.

*Corresponding author (robertoponce@udd.cl).

${ }^{2}$ Universidad Politécnica de Madrid, Departamento de Economía y Ciencias Sociales Agrarias, Avda. Complutense 3, 28040, Madrid, España.

${ }^{3} \mathrm{Ca}$ 'Foscari University, Department of Economics, S. Giobbe 873, 30121 Venezia, Italy.

Received: 16 December 2013

Accepted: 7 August 2014.

doi:10.4067/S0718-58392014000400005
(Massey and Huitema, 2013). Nevertheless, it can at least be considered as an application context for agricultural policy. A cost benefit analysis of technical and policy actions should be the basis to assist stakeholders to develop measures to reduce the vulnerability to climate change. But policies crafted to operate within a certain range of conditions may produce unexpected outcomes if applied outside of that range (Swanson et al., 2010; Iglesias et al., 2012).

The assessment of the economic impacts of climate change on the agricultural sector requires an approach aimed to provide a detailed picture of the sector and the relationships within it. In this regard, bottom-up approaches (i.e., in particular models applied at local level, but driven by global forces) could be an effective tool to evaluate the economic impacts of climate change on the agricultural sector.

Bottom-up approaches, such as bio-economic agricultural models, simulate the agents' -e.g., farmers' - behavior, allowing for an ex-ante evaluation of policy interventions. Agricultural models range from studies at farm level, to studies including the whole agricultural sector. The main difference is in the distinction between endogenous and exogenous variables and in particular price assumptions.

Agricultural supply models represent the agricultural sector through a series of behavioral equations, which are solved in order to maximize the farm income or the regional income, subject to technological, environmental, and institutional constraints (Howitt, 2005). The wide use of agricultural models is underpinned in the limited 
amount of data required for their development (Hazzell and Norton, 1986; Howitt, 1995; Howitt et al., 2010).

Agricultural supply models in their multiple versions have been applied to several agricultural issues, including models analyzing the expected impacts of the Common Agricultural Policy (CAP) in regions such as Belgium, UK, Greece, Germany, and Sweden (de Frahan et al., 2007; Blanco et al., 2008; Mattas et al., 2011). Other applications include the estimation of the economic value of water and land (Howitt et al., 2001; Iglesias and Blanco, 2008; Medellín-Azuara et al., 2009; Kan et al., 2009), and climate change impacts (Henseler et al., 2009; Howitt et al., 2010; Medellín-Azuara et al., 2011; Howitt et al., 2012) (for reviews of other case studies see Heckelei et al., 2012).

The economic assessment of climate change impacts on the Chilean agricultural sector has been analyzed from different perspectives in recent years. From an economic perspective, González and Velasco (2008) developed one of the first studies on this subject. In their article authors analyzed the impact of climate change on the economic value of land, using the Ricardian approach (Mendelsohn et al., 1994). They reported a statistical relationship between climatic variables and the land value, with moderate explanatory power ( $\mathrm{R}$-square reported is around $30 \%)$. Nevertheless, an interesting finding is that the scenarios modeled showed less impact on the value of land than previous studies developed in Latin America.

On the other hand, from a productive perspective the first study was developed by the University of Chile's AGRIMED center (Center on Agricultural and Environment) in 2008 (Santibáñez et al., 2008). In this study, authors analyzed the impacts that climate change could have on the Chilean agricultural sector. The analysis is conducted using the Modelo Simulador de Productividad de Cultivos (SIMPROC model) specifically developed for the Chilean agricultural sector (Santibáñez, 2001). The results are computed at the commune level (340 communes), while the scenarios modeled are the IPCC A2 and B2 for two periods of time, around 2040 and 2070 (IPCC, 2000). According to the results, the large productive impacts are located in the northern region of Chile.

Other economic studies include Bárcena et al. (2009) and ODEPA (2010). In 2009, the Economic Commission for Latin America and the Caribbean (CEPAL) conducted a study analyzing the economic impacts of climate change in Chile (Bárcena et al., 2009). Although this study did not focus on the agricultural sector, this sector was analyzed as a part of the Chilean economy. Using an econometric model, the authors simulated the expected changes in land allocation due to climate change. The analyzed crop yield changes and activities are those computed by Santibáñez et al. (2008). Their results suggest that net incomes will increase from the Biobío Region to the south, while in the northern region the net incomes will decrease. In the worst-case scenario, the agricultural sector will lose $15 \%$ of its income (A2 scenario); while in the best-case scenario the incomes will increase by $1 \%$ (B2 scenario). The Agrarian Policies and Studies Bureau (ODEPA) conducted a study at the national level in 2010 in order to account for the magnitude of the economic impacts climate change could have on the Chilean agricultural sector (ODEPA, 2010). The study updated the information generated by Santibáñez et al. (2008), increasing the number of activities analyzed from 17 to 25 . In this study, the authors used an econometric model in order to account for the land allocation change due to the expected yield changes. The main conclusions of the study show that climate change will have uneven impacts across the country, with the northern region being the most affected. Results also show a southward movement of the land allocated to annual crops and cereals. In general terms, a $7 \%$ decrease in the land devoted to cereal and fruit production is expected under the A2-2040 scenario, while the net income decreases by $5 \%$.

In general, there are a growing number of studies addressing climate change impacts using economic models and, hence, taking into account farmers' adaptation strategies (Fischer et al., 2005; Howitt et al., 2010; Nelson et al., 2010; Medellín-Azuara et al., 2011; Nelson et al., 2013; von Lampe et al., 2014). However, the economic impacts of climate change on the Chilean agricultural sector have mainly been analyzed through the use of econometric techniques, or by using simple accounting methods, disregarding the adaptation options available for the farmers.

The main objective of this paper was to analyze the economic impacts of changes in yields, due to climate change, on the Chilean agricultural sector. The analysis is conducted using a non-linear agricultural supply model. The model is designed specifically for the analysis of the Chilean agricultural sector, and it accounts for uncertainty about agricultural yields through the use of Monte Carlo simulations.

\section{MATERIALS AND METHODS}

\section{Model description}

The Agricultural Supply model (ASM) is a mathematical programming model designed to analyze the agricultural sector with high geographical disaggregation. It includes the major agricultural activities within the area, and differentiates between water provision systems (rainfed and irrigated), among other features.

The core of ASM includes the behavior of the agricultural producers, which is characterized by detailed information at the producer level in order to represent a system of outputs supply and inputs demand, which is the result of the assumed profit maximization behavior. The information is differentiated by activity and geographical area, including: area planted, yields, variable costs, and 
labor demand, which is used to compute total costs, gross margin, and net revenues. The information presented above is complemented with supply elasticities for each activity. The core model is optimized considering a series of endowment restrictions, such as: total land, irrigated land, and water availability.

The model is calibrated to a single reference period using Positive Mathematical Programming (PMP). This approach was formalized by Howitt (1995), but has been used in agricultural economics for almost three decades. The PMP considers the farmer's optimization process, allowing for a perfect calibration of area planted, for the full range of agricultural activities, avoiding the dependency between parameters and constraints. The approach followed in this paper is extensively used in agricultural economics due to its accuracy when the model calibration is based on a single base year (complemented with exogenous price elasticities) (Heckelei and Britz, 2005; Howitt et al., 2010; Medellín-Azuara et al., 2011).

\section{Model structure}

Positive Mathematical Programming is three-step procedure for model calibration assuming that farmers optimize input use in order to maximize their profits. In the first step, a linear programming model is defined in order to maximize the region's farm net income by allocating land and irrigation water to crops. This model takes all relevant data and farming conditions into account, and includes: 1) the objective function describing the farmers' behavior as rational agents; 2) a set of explicit constraints related to resource availability (land, irrigated land, and water), and institutional conditions (policy and environmental).

Along with the resource and non-negativity constraints, the model includes a calibration constraint. The main decision variables are cropland allocation and irrigation technology choice; $X_{r, a, s}$ denotes the area (ha) allocated to crop $a$ with farming system $s$ in region $r$. The model can be compactly written as (subscript $i$ denotes the resource type):

$$
\begin{gathered}
Z=\sum_{r} \sum_{a} \sum_{s}\left(P a * Y_{r, a, s}-A C_{r, a, s}\right) * X_{r, a, s} \\
A C_{r, a, s}=v \operatorname{cost}_{r, a, s} \\
\sum_{a} \sum_{s} r_{i, r, a, s} * X_{r, a, s} \leq b_{i, r} \\
X_{r, a, s}=X_{r, a, s}^{0}+e_{r, a, s} \\
X_{r, a, s} \geq 0
\end{gathered}
$$

In Equation [1], $Z$ is the objective function value, $A C_{r, a, s}$ is the vector of average costs per unit of activity, $p_{a}$ is the price of crop $a, y_{r, a, s}$ is the yield per hectare of crop $a$ in region $r$ using system $s$. In Equation [2] $v \cos t_{r, a, s}$ represents the observed variable costs per unit of activity, while in Equation [3] $r_{i, r, a, s}$ represents the matrix of coefficients in resource/policy constraints, and $b_{i, r}$ is the vector of available resource quantities. Equation [4] represents the calibration constraint that bounds the model (in its linear specification) to the observed activity levels in the base year, in which $X_{r, a, s}^{0}$ denotes the land allocation in the base year, and $e_{r, a, s}$ represents a small deviation from the base year land allocation. Finally, Equation [5] represents the non-negativity constraints on land allocation.

In the second step, the dual values associated with the calibration constraint are used to specify a non-linear cost function, in which the marginal costs are equal to the market prices at the base year (Howitt, 1995; Heckelei, 2002). The model assumes constant average revenues (regardless of the level of activity) and increasing average costs, as well as a non-linear cost function, which captures all production conditions not explicitly modeled. Following Blanco et al. (2008) and Howitt et al. (2010; 2012), the average cost function of activity $a$ can be written:

$$
A C_{r, a, s}=\alpha_{r, a, s} *\left(X_{r, a, s}\right)^{\beta r, a, s}
$$

The cost function parameters $\alpha_{r, a, s}$ and $\beta_{r, a, s}$ are derived from a profit-maximizing equilibrium that maximizes Equation [1] subject to [2], [3], [4], and [5].

Additional conditions are: 1) In the base year, the estimated average cost equals the observed average cost for each activity; 2) supply elasticities are exogenous; 3 ) the assumption of optimal farmers' behavior can be extended to new activities, and cost function parameters can then be approximated by means of optimality conditions.

In the third step, once the cost function parameters have been derived, the calibrated non-linear model is specified. The ASM maximizes the net income Equation [1] subject to [3], [5], and [6].

The model as presented above reproduces the activity levels observed for the base year and allows us to simulate hypothetical climate change scenarios. The ASM anticipates farmer's responses, in particular changes in cropland allocation and water provision systems, motivated by the differentiated effect of climate change on crop productivity, across crops and across regions. Further, the model incorporates all the available information, and it uses calibrated parameters to model all the conditions that -due to lack of data- could not be considered in an explicit way. The model is consistent with economic theory, and its structure is flexible enough to incorporate all relevant environmental constraints and policy instruments (Howitt, 1995; Heckelei, 2002; Howitt, 2005; de Frahan et al., 2007; Heckelei et al., 2012).

Uncertainty is included in the modeling framework using the Monte Carlo method. In this specific case, the model assumes that the agricultural yields are random variables following a Gamma distribution. Thus, several sets of agricultural yields are simulated using both uniform pseudo-random numbers and the inverse probability distribution function (Hardaker et al., 1997).

\section{RESULTS AND DISCUSSION}

Due to its geographical characteristics, Chile has various climatic conditions throughout its diverse regions. The climate ranges from desert in the north to alpine tundra 
and glaciers in the eastern and southeastern areas. At the administrative scale, northern Chile, characterized by an arid and semiarid climate, includes Arica y Parinacota, Tarapacá, Antofagasta and Atacama Regions. Central Chile, characterized by a Mediterranean climate, includes Coquimbo, Valparaíso, Metropolitana, Libertador General Bernardo O'Higgins, and Maule Regions. Southern Chile, characterized by an oceanic climate, includes Biobío, La Araucanía, Los Lagos, and Los Ríos Regions, while the austral area, characterized by a sub-polar climate, includes Aysén del General Carlos Ibáñez del Campo and Magallanes y la Antártica Chilena Regions.

Within the climatic context presented above, the total agricultural land (18.4 million ha) is divided as follows: 1.7 million ha cultivated land, 14.03 million ha grassland, and 2.7 million ha forested land. Considering only the cultivated land (1.7 million ha), $76 \%$ is devoted to annual and permanent crops, while $23.5 \%$ is devoted to fodder (INE, 2007).

\section{Model specification}

The application of the ASM included a smaller area than those considered in previous studies. The area being analyzed here included Atacama Region in the north to Los Lagos Region in the south. This area included 265 communes, grouped into 36 provinces, and 10 regions. The agricultural sector was represented by 22 activities, aggregated according to the following categories: Crops (10), fruits (10), and forestry (2); the model considers irrigated and rainfed activities, accounting for 3.3 million ha.

The crops considered were: rice (irrigated), oats (rainfed), common beans (irrigated), maize (irrigated), potatoes (irrigated and rainfed), alfalfa (irrigated), sugar beet (irrigated), and wheat (irrigated and rainfed). The fruits considered were: cherries, plums, peaches, apples, oranges, walnuts, olives, avocadoes, pears, grapes, and vine grapes, all of them irrigated activities. Finally, the model also included the area devoted to forestry, including: pine and eucalyptus, both rainfed activities. The agricultural sector depicted above represents $82.4 \%$ of the agricultural activities developed within the study area. The model accounts only for those activities that have a market price, excluding grassland from the analysis.

The core information used in the model (area, production, yield) was from the year 2007, and comes from the National Agricultural Census (INE, 2007), considering a disaggregation at communal level. The information about costs per commune, activities and watering systems (irrigated, rainfed), as well as labor intensity is the same information used in the study of Chilean Agrarian Policies and Studies Bureau (ODEPA, 2010); prices were taken from the ODEPA website, while the elasticities used to calibrate the model were collected from previous studies (Quiroz et al., 1995; CAPRI Model, 2008; Foster et al., 2011).
Two scenarios were modeled in order to assess the economic impacts of changes in agricultural yields. In the first one, the net farm agricultural income was computed for the base year (2007) using the agricultural yields corresponding to this year, while in the second scenario the net farm agricultural income in 2007 was computed using the yields computed by Santibáñez et al. (2008) assuming the A2 scenario for 2040. Thus, the economic impacts of changes in agricultural yields were computed as the difference in the net farm agricultural income for both scenarios.

The potential agricultural yields by zone are presented in Table 1, in which northern zone includes the Regions: Atacama, Coquimbo, and Valparaíso; central zone includes Metropolitana, Libertador General Bernardo O’Higgins, and Maule Regions; while southern zone includes Biobío, La Araucanía, Los Ríos, and Los Lagos Regions. The ASM was developed using the General Algebraic Modeling System (GAMS) software (GAMS Development Corporation, Washington, D.C., USA).

\section{Results of modeling}

At the national level, the expected changes in agricultural yields have a minor impact on the total land allocation, with total agricultural land decreasing by 46600 ha. However, as expected, the estimated impacts across regions are uneven, with the largest impacts in the northern region. For instance, both the Atacama and Coquimbo Regions decrease their agricultural land by $40 \%$, while for the central zone the decrease is only $7.4 \%$ (on average), with a decrease of 14825 ha. On the other hand, from the

Table 1. Climate change scenario: Average expected yields.

\begin{tabular}{|c|c|c|c|c|c|c|}
\hline \multirow[b]{2}{*}{ Activity } & \multicolumn{2}{|c|}{ Northern Zone } & \multicolumn{2}{|c|}{ Central Zone } & \multicolumn{2}{|c|}{ Southern Zone } \\
\hline & Baseline & $\begin{array}{l}\text { Climate } \\
\text { change }\end{array}$ & Baseline & $\begin{array}{l}\text { Climate } \\
\text { change }\end{array}$ & Baseline & $\begin{array}{l}\text { Climate } \\
\text { change }\end{array}$ \\
\hline & & & $\mathrm{th}$ & $a^{-1}$ & & \\
\hline Crops average & 4 & 3.812 & 12.860 & 8.787 & 15.165 & 11.130 \\
\hline Alfalfa & 13.459 & 13.809 & 18.442 & 19.790 & 21.376 & 24.488 \\
\hline Common bean & 1.320 & 0.532 & 1.710 & 1.469 & 1.275 & 1.170 \\
\hline Maize & 6.380 & 3.886 & 9.473 & 7.947 & 6.925 & 6.204 \\
\hline Oat & 3.026 & 2.790 & 2.465 & 1.437 & 3.177 & 4.055 \\
\hline Rainfed potato & 1.200 & 10.841 & 3.991 & 11.995 & 10.647 & 16.494 \\
\hline Irrigated potato & 10.146 & 4.177 & 12.699 & 8.785 & 14.898 & 18.031 \\
\hline Rice & 0 & 0 & 5.046 & 2.920 & 4.252 & 2.283 \\
\hline Sugar beet & 0 & 0 & 67.333 & 27.600 & 81.461 & 30.957 \\
\hline Rainfed wheat & 1.928 & 1.689 & 2.782 & 1.852 & 3.683 & 4.278 \\
\hline Irrigated wheat & 2.543 & 0.399 & 4.664 & 4.073 & 3.958 & 3.338 \\
\hline Fruits Average & 14.805 & 5.524 & 16.035 & 13.142 & 12.746 & 10.044 \\
\hline Apple & 28.571 & 4.605 & 34.376 & 19.114 & 30.328 & 27.159 \\
\hline Avocado & 8.003 & 7.490 & 8.704 & 10.212 & 9.437 & 4.226 \\
\hline Cherry & 6.550 & 1.913 & 5.313 & 5.023 & 3.206 & 3.335 \\
\hline Grapes & 19.140 & 5.132 & 20.951 & 16.292 & 15.319 & 12.248 \\
\hline Olive & 10.979 & 4.310 & 12.760 & 11.316 & 13.026 & 7.476 \\
\hline Orange & 18.798 & 16.671 & 20.350 & 23.585 & 19.479 & 9.759 \\
\hline Peach & 22.796 & 7.693 & 22.980 & 20.197 & 13.836 & 13.344 \\
\hline Pear & 12.171 & 2.057 & 15.274 & 8.625 & 16.108 & 12.133 \\
\hline Plum & 23.085 & 6.985 & 21.836 & 18.339 & 8.525 & 12.116 \\
\hline Vineyard & 9.864 & 2.941 & 11.151 & 9.337 & 8.787 & 7.020 \\
\hline Walnut & 2.892 & 0.969 & 2.693 & 2.525 & 2.154 & 1.668 \\
\hline Forest Average & 0.113 & 0.088 & 0.194 & 0.169 & 0.235 & 0.265 \\
\hline Pine & 0.177 & 0.107 & 0.240 & 0.200 & 0.291 & 0.317 \\
\hline Eucalyptus & 0.049 & 0.068 & 0.148 & 0.138 & 0.179 & 0.212 \\
\hline
\end{tabular}


Biobío Region to the south, the decrease in agricultural land is negligible (Table 2).

Results by zone and activity show that there is not a direct relationship between the expected change in agricultural yields and the final change in land allocation. The reason for this apparent contradiction is that the final land allocated to each activity is function of its relative profit respect to other activities. In this regard, agricultural yields are one component of the profit level, along with prices and costs. For instance, within the northern zone, on the average, agricultural yields decrease by $51 \%$ with respect to the baseline, while the expected average change in land allocation is $-16 \%$. The same stands for the central and southern zones, in which a large change in agricultural yields $(-24 \%)$ is foreseen, but the change in total agricultural land is quite small, $-2.5 \%$ and $-0.1 \%$, respectively.

At the activity level, in the northern zone a decrease in irrigated potatoes yields of $58 \%$ drives a $98 \%$ decrease in its land allocation. This final land allocation shows that despite the high potential productivity of rainfed potatoes under the climate change scenario, this activity is less profitable than forest production, which actually increases its land allocation.

Within the central zone, the increase in rainfed potatoes yield (from 3.9 to $11.9 \mathrm{t} \mathrm{ha}^{-1}$ ) would drive an increase of nine times in the land allocated to it. On the other hand, a decrease in sugar beet yields $(60 \%)$ drives a small decrease in the land allocated to this crop (4\%). The same would happen with the land allocated to rice that increases for $1.5 \%$ regardless the large decrease in yields $(-42 \%)$.

The southern zone shows an increase in the land allocated to crops $(26 \%)$ despite the expected decrease in crop yield $(-26.6 \%)$. Within crops, only alfalfa, rice, and sugar beet show a decrease in their land allocation. Regarding fruits, the land allocated to avocado will increase by $13 \%$, independently of the expected change in yields $(-55 \%)$, the same happens with land allocated to oranges.

Agricultural production suffers from large changes due to the new land allocation across the country, with the largest negative changes faced by grape $(-86 \%)$, pear

Table 2. Land allocation: Baseline and climate change.

\begin{tabular}{|c|c|c|c|c|}
\hline \multirow[b]{2}{*}{ Region } & \multicolumn{2}{|c|}{ Rainfed land } & \multicolumn{2}{|c|}{ Irrigated land } \\
\hline & Baseline & $\begin{array}{l}\text { Climate } \\
\text { change }\end{array}$ & Baseline & $\begin{array}{l}\text { Climate } \\
\text { change }\end{array}$ \\
\hline Atacama & 0.0 & 0.0 & 3151.8 & 1631.7 \\
\hline Coquimbo & 342.3 & 362.6 & 28770.0 & 15818.1 \\
\hline Valparaíso & 46094.8 & 48036.6 & 45222.0 & 38202.7 \\
\hline Metropolitana & 7847.2 & 9946.6 & 68945.5 & 52020.5 \\
\hline $\begin{array}{l}\text { Libertador General } \\
\text { Bernardo O'Higgins }\end{array}$ & 133900.0 & 136089.2 & 140459.8 & 132241.8 \\
\hline Maule & 489754.8 & 491913.3 & 150286.1 & 144487.7 \\
\hline Biobío & 1019464.0 & 1020940.5 & 78712.9 & 74999.4 \\
\hline La Araucanía & 702407.2 & 702011.3 & 10495.3 & 10531.3 \\
\hline Los Ríos & 253127.0 & 253094.4 & 1366.0 & 1398.6 \\
\hline Los Lagos & 110027.4 & 109997.4 & 413.9 & 443.9 \\
\hline
\end{tabular}

$(-54 \%)$, and walnut $(-38 \%)$. On the other hand, most of the increase in production is associated to rainfed activities, such as: oat $(125 \%)$, potato $(84 \%)$, and wheat $(38 \%)$. In general, the total agricultural production changes from 10.6 million to 10.5 million tons. Results by zone and activity show that the impact on crop production is unevenly distributed across the country, with crop production decreasing by $37 \%$ in the northern zone, while in the southern zone it increases by $38 \%$. Fruit production decreases in all regions, ranging from $53 \%$ in the northern zone to $11 \%$ in the southern zone. Forest increases its production in the northern zone $(8 \%)$, while the central and southern zones show a small decrease, $4 \%$ and $2 \%$ respectively.

In average, the northern zone will decrease its agricultural production by $492000 \mathrm{t}$ (-48\%). Among crops within the northern zone, maize, potato, and wheat show the main decrease, $83 \%, 99 \%$, and $52 \%$ respectively, equivalent to $92800 \mathrm{t}$. On the other hand, this zone will lose 401000 t fruits (-53\%), with grapes, pears, and olives as the most affected activities.

The largest impact of climate change on the central zone is represented by the $19 \%$ decrease in fruits production $(627000 \mathrm{t})$. Most of this decrease is related to apple $(262000 \mathrm{t})$ and vineyard (267 $000 \mathrm{t})$, which represents $-84 \%$ of apple production and $-69 \%$ of vineyard production. Regarding crop production, a decrease of 127 $000 \mathrm{t}(6 \%)$ is expected, with maize and potato accounting for the large share.

The southern zone shows the largest decrease in production with $1142000 \mathrm{t}$, representing 28\% of its production. Detailed results show that crop production increases for $1198000 \mathrm{t}(38 \%)$, fruits production decreases by $11 \%(45000 \mathrm{t})$, and forest production decreases by 2\% (10 400 t). Among crops, oat and potato increase their production more than $100 \%$, followed by wheat (46\%). Pear and apple production show the largest decrease in production, $61 \%$ and $25 \%$ respectively, while the other fruit activities increase their production within the range of 6\%-39\% (Table 3 ).

All the changes described above drive a $2.7 \%$ decrease in the agricultural net income, from USD 2235 million to USD 2176 million (equivalent to USD 59 million). At the regional level, 6 out of 10 regions show a decrease in net incomes, from Atacama to Maule Regions. Only the regions within the southern zone could have benefits due to climate change.

In relative terms, the regions within the northern zone decrease their net income by $50 \%$, in the central zone the reduction was $-17 \%$, while the southern zone increased its income by $40 \%$. At regional level, the most affected appeared to be Atacama Region, while Los Lagos Region gained the most. In Atacama Region impacts are associated to the decrease in production of olive, potato, vineyard, and avocado, this activities account for the $97 \%$ of the change in the agricultural production within the 
Table 3. Agricultural production by activity and zone.

\begin{tabular}{|c|c|c|c|c|c|c|}
\hline \multirow[b]{2}{*}{ Activity } & \multicolumn{2}{|c|}{ Northern Zone } & \multicolumn{2}{|c|}{ Central Zone } & \multicolumn{2}{|c|}{ Southern Zone } \\
\hline & Baseline & $\begin{array}{l}\text { Climate } \\
\text { e change }\end{array}$ & Baseline & $\begin{array}{l}\text { Climate } \\
\text { change }\end{array}$ & Baseline & $\begin{array}{l}\text { Climate } \\
\text { change }\end{array}$ \\
\hline Total crops & 248880 & 156995 & 2171518 & 2043777 & 3129134 & 4328057 \\
\hline Alfalfa & 145376 & 147217 & 449196 & 552139 & 190931 & 156308 \\
\hline Common bean & 533 & 25 & 10216 & 10155 & 3430 & 3684 \\
\hline Maize & 15797 & 2609 & 966374 & 783353 & 93439 & 98260 \\
\hline Oat & 1592 & 1184 & 897 & 399 & 278586 & 632891 \\
\hline Potato & 74361 & 618 & 141961 & 89778 & 557283 & 1337459 \\
\hline Rice & & & 89382 & 92745 & 18941 & 13337 \\
\hline Sugar beet & & & 378285 & 384164 & 1072667 & 755415 \\
\hline Wheat & 11222 & 5341 & 135206 & 131044 & 913857 & 1330704 \\
\hline Total fruits & 761592 & 360480 & 3261668 & 2634250 & 397058 & 351577 \\
\hline Apple & 9532 & 1495 & 1048318 & 785853 & 190009 & 142883 \\
\hline Avocado & 227211 & 226237 & 81206 & 102729 & 205 & 284 \\
\hline Cherry & 1061 & 263 & 35701 & 45051 & 8987 & 10529 \\
\hline Grapes & 135325 & 4258 & 83801 & 25233 & & \\
\hline Olive & 48338 & 9098 & 102576 & 81693 & 11139 & 15483 \\
\hline Orange & 42122 & 38778 & 94107 & 139749 & 127 & 171 \\
\hline Peach & 122403 & 28239 & 242055 & 254762 & 786 & 961 \\
\hline Pear & 4030 & 288 & 86198 & 41278 & 613 & 237 \\
\hline Plum & 6821 & 1898 & 350583 & 293297 & 236 & 250 \\
\hline Vineyard & 150768 & 45635 & 1114380 & 846625 & 184065 & 179689 \\
\hline Walnut & 13982 & 4291 & 22742 & 17981 & 891 & 1089 \\
\hline Total forest & 5561 & 6012 & 154761 & 147859 & 497214 & 486748 \\
\hline Pine & 1474 & 1346 & 136485 & 126084 & 353423 & 320735 \\
\hline Eucalyptus & 4087 & 4666 & 18277 & 21775 & 143791 & 166013 \\
\hline
\end{tabular}

region. On the other hand, our simulations show that Los Lagos Region doubles its agricultural production, with potato, wheat, and oat being the most important activities. A detailed picture at national level is presented in Table 4.

Regarding activities, the distributional effects among farmers are large. Annual crop producers are better-off under the climate change scenario than in the baseline, while fruits producers are worst-off under the climate change scenario. Farmers growing rainfed crops increase their net income by $88 \%$ (in average), with oat (132\%), potato $(93 \%)$, and wheat (39\%) being the most profitable activities (Figure 1). In general, farmers growing crops will increase their income by USD 141 million. On the other hand, only those farmers growing cherry, orange, and avocado will increase their income (USD 24 million), while those growing grape and apple will decrease their income by USD 157 million. In general, fruits producers will decrease their income by USD 208 million.

All the results were presented so far as crisp values, without consideration of probabilities and uncertainty. In order to account for the uncertainty associated to

Table 4. Economic impacts of climate change: Net agricultural income.

\begin{tabular}{lcc}
\hline Region & $\begin{array}{c}\text { Baseline } \\
\text { (million USD) }\end{array}$ & $\begin{array}{c}\text { Climate change } \\
\text { (million USD) }\end{array}$ \\
\hline Atacama & 13 & 4 \\
Coquimbo & 112 & 46 \\
Valparaíso & 202 & 156 \\
Metropolitana & 186 & 111 \\
Libertador General Bernardo O'Higgins & 388 & 373 \\
Maule & 430 & 398 \\
Biobío & 453 & 494 \\
La Araucanía & 297 & 363 \\
Los Ríos & 105 & 130 \\
Los Lagos & 50 & 101 \\
Total & 2235 & 2176 \\
\hline
\end{tabular}

the change in agricultural yields, a series of Monte Carlo simulations were developed. The objective was to determine the probability of a certain income level's occurrence, depending on the yield scenario analyzed. As it was established before, our model assumes that the agricultural yields follow a Gamma distribution. For simplicity, the Gamma distribution parameters are computed per activity for the whole country, using the mean and the variance of the agricultural yield sample. In order to compute the cumulative distribution function (CDF) for the net agricultural income, a series of 400 yield scenarios were computed. The CDF is presented in Figure 2.

The analysis of the net agricultural income distribution shows that the $25^{\text {th }}$ percentile was USD 627 million, $50^{\text {th }}$ percentile was USD 1155 million, and $75^{\text {th }}$ percentile was USD 2083 million. Considering these figures, the income reported for the climate change scenario, USD 2176 million, was above the $75^{\text {th }}$ percentile, thus supporting the robustness of results obtained, even when consideration of yield variability is included in the calculations.

In general, the results reported here are consistent with those reported by previous studies for Chile, showing large economic impacts on the northern zone. However, the ASM does not predict large economic consequences at the country level as previous studies did. Previous studies quantified the economic impacts of climate change, under the A2-2040 scenario, with losses between 10\% (Bárcena et al., 2009) to 5\% (ODEPA, 2010) of the agricultural income, while our results quantified those impacts in $-3 \%$ of the agricultural income. This difference is related to the methodology used, in which the farmer could reallocate land in order to maximize the net income under different yield conditions. On the other hand, the results could be useful for the implementation of the National Plan for Climate Change Adaptation of Agriculture (MMA, 2013), in which irrigation improvement, a better access to markets, and the optimization of the use of water resources are defined as strategic actions to cope with climate change impacts at national level.

In a wider context, our results are in line with other studies across the world in which climate change could threaten the agricultural sector. For instance, Di Falco and Veronesi (2013) analyzed the impact of different adaptation strategies on crop net revenues in the Nile Basin of Ethiopia, finding significant positive effects of adaptation (e.g. changing crop varieties) on farm net revenues. At larger geographical scale (11 countries in Africa, with 10000 farm household surveys) Hassan (2010) demonstrates that African agriculture and the related welfare are vulnerable to climate change, in particular for what concerns crop and livestock farming in dry lands, while Dono et al. (2013) observed that the most important economic impacts are derived from yield instability. 


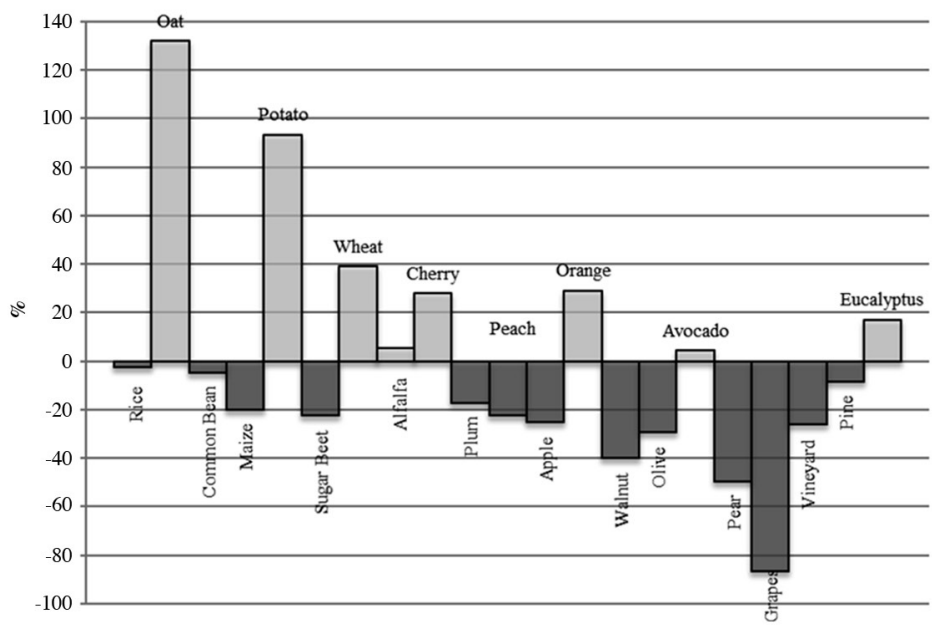

Figure 1. Agricultural net income change.

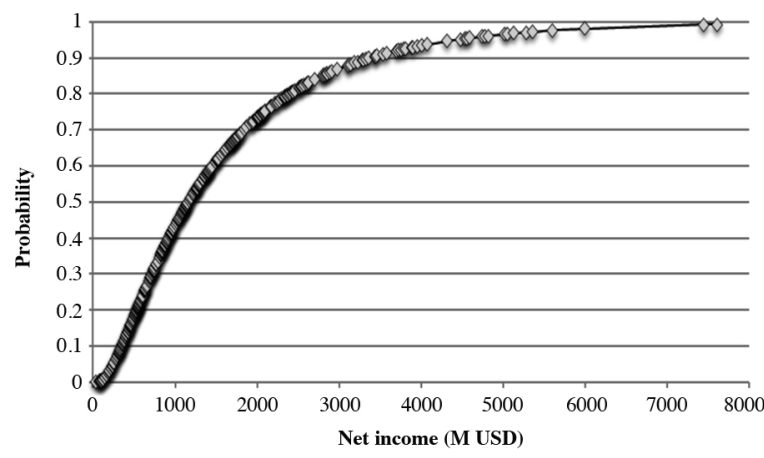

Figure 2. Cumulative distribution function: Agricultural net income.

\section{CONCLUSIONS}

Considering the results, the major conclusion of this study is that the Chilean agricultural sector is vulnerable to the change in agricultural yields as a consequence of climate change. At the regional level, our model shows substantial re-allocations of land, with the northern zone showing larger changes. However, this land reallocation does not seriously impact the total agricultural production at the national level. Therefore, according to the results, even if climate change may not have large absolute consequences, it may produce large distributional consequences, with fruits producers being worst-off than crops producers. In this regard, climate change could threaten a key economic sector, since fruits account for $31 \%$ of total food export. On the other hand, the statistical analysis confirmed the robustness of our results.

However, besides the high level of detail in which the agricultural sector is modeled, some drawbacks remain and they should be considered in terms of future research needs. First of all, even if our model considers a fine administrative disaggregation at commune level, results could be substantially improved by the inclusion of an agro-ecological zone disaggregation, thus providing a better representation of agro-climatic characteristics and their relationships with land suitability and productivity. Secondly, the magnitude of the projected impacts of climate change on the whole agricultural sector suggests that it is reasonable to expect that changes in production will be large enough to drive a change in agricultural prices. The Agricultural Supply model is currently not able to analyze this scenario, due to the assumptions about prices. One solution could be to move from supply modeling to sector modeling, or to general equilibrium modeling. The final choice will depend on the data availability. Another important consideration is that, although the model accounts for adaptation by allowing for changes in land allocation to cope with climate change, it does not consider other adaptation options, such as the incorporation of different techniques or technologies for farm management.

\section{ACKNOWLEDGEMENTS}

We would like to thanks to the Graduate School of Ca'Foscari University of Venice for the support provided for this research and to the International Research Development Research Centre (IDRC-Canada) for the partial financial support to this research, as part of the project: "Evaluación del bienestar y los impactos económicos del cambio climático en el suministro y demanda de agua en Chile, Colombia y Bolivia”.

\section{LITERATURE CITED}

Bárcena, A., A. Prado, J.L. Samaniego, y S. Malchik. 2009. La economía del cambio climático en Chile. Síntesis. Colección Documentos de Proyectos. Comisión Económica para América Latina y el Caribe (CEPAL), Naciones Unidas, Santiago, Chile. Available at http://www.eclac.cl/publicaciones/xml/8/37858/ W288.pdf (accessed August 2013). 
Bates, B., Z. Kundzewicz, S. Wu, and J. Palutikof (eds.) 2008. Climate change and water. $210 \mathrm{p}$. Technical Paper of the Intergovernmental Panel on Climate Change (IPCC), Geneva, Switzerland.

Blanco, M., R. Cortignani, and S. Severini. 2008. Evaluating changes in cropping patterns due to the 2003 CAP Reform. An ex-post analysis of different PMP approaches considering new activities. $107^{\text {th }}$ EAAE Seminar Modelling of Agricultural and Rural Development Policies, Sevilla. 29 January-1 February. European Association of Agricultural Economists (EAAE), Sevilla, España.

CAPRI Model. 2008. CAPRI Model Documentation. In Britz, W., and P. Witzke (eds.) Available at http://www.capri-model.org/ (accessed September 2013).

de Frahan, B.H., J. Buysse, P. Polomé, B. Fernagut, O. Harmignie, L. Lauwers, et al. 2007. Positive mathematical programming for agricultural and environmental policy analysis: Review and practice. p. 129-154. In Weintraub, A., C. Romero, T. Bjornda, R. Epstein, and J. Miranda (eds.) Handbook of Operations Research in Natural Resources. Springer, New York, USA.

Di Falco, S., and M. Veronesi. 2013. How can African agriculture adapt to climate change? A counterfactual analysis from Ethiopia. Land Economics 89:743-766.

Dono, G., R. Cortignani, L. Doro, L. Giraldo, L. Ledda, M. Pasqui, et al. 2013. Adapting to uncertainty associated with short-term climate variability changes in irrigated Mediterranean farming systems. Agricultural Systems 117:1-12.

Fischer, G., M. Shah, F.N. Tubiello, and H. van Velhuizen. 2005. Socio-economic and climate change impacts on agriculture: an integrated assessment, 1990-2080. Philosophical Transactions of the Royal Society B: Biological Sciences 360:2067-2083.

Foster, W., J. López de Lérida, y A. Valdés. 2011. Impacto del nivel de distorsiones en el sector agrícola nacional. Ministerio de Agricultura, Pontificia Universidad Católica de Chile, Facultad de Agronomía e Ingeniería Forestal, Departamento de Economía Agraria, Santiago, Chile.

González, J., and R. Velasco. 2008. Evaluation of the impacts of climatic change on the economic value of land in agricultural systems in Chile. Chilean Journal of Agricultural Research 68:5668 .

Hardaker, J., R. Huirne, and J. Anderson. 1997. Coping with risk in agriculture. CAB International, Oxon, UK.

Hassan, R.M. 2010. Implications of climate change for agricultural sector performance in Africa: Policy challenges and research agenda. Journal of African Economies 19 (Suppl. 2):ii77-ii105.

Hazzell, P.B.R., and R. Norton. 1986. Mathematical programming for economic analysis in agriculture. Collier Macmillan, New York, USA.

Heckelei, T. 2002. Calibration and estimation of programming models for agricultural supply analysis. 169 p. University of Bonn, Bonn, Germany. Available at http://www.ilr.uni-bonn.de/ agpo/staff/heckelei/heckelei_hab.pdf (accessed 22 July 2014).

Heckelei, T., and W. Britz. 2005. Models based on positive mathematical programming: State of the art and further extensions. p. 48-73. Modelling Agricultural Policies: State of the Art and New Challenges. Proceedings of the $89^{\text {th }}$ European Seminar of the EAAE, Parma. 3-5 February. University of Parma, Department of Economic and Quantitative Studies, Parma, Italy.

Heckelei, T., W. Britz, and Y. Zhang. 2012. Positive mathematical programming approaches - Recent developments in literature and applied modelling. Bio-based and Applied Economics 1:109-124.

Henseler, M., A. Wirsig, S. Herrmann, T. Krimly, and S. Dabbert. 2009. Modeling the impact of global change on regional agricultural land use through an activity-based non-linear programming approach. Agricultural Systems 100:31-42.

Howitt, R. 1995. Positive mathematical programming. American Journal of Agricultural Economics 77:329-342.

Howitt, R. 2005. PMP Based production models-development and integration. XI European Association of Agricultural Economists (EAAE), Copenhagen, Denmark, 23-27 August. EAAE, The Hague, The Netherlands.
Howitt, R.E., D. MacEwan, J. Medellín-Azuara, and J.R. Lund. 2010. Economic modeling of agriculture and water in California using the statewide agricultural production model. 25 p. University of California, Davis, California, USA. Available at http://swap. ucdavis.edu (accessed September 2013).

Howitt, R., J. Medellín-Azuara, and D. MacEwan. 2012. Economic impacts of climate-related yield changes in California. Climatic Change 109:S387-S405.

Howitt, R., K. Ward, and S. Msangi. 2001. Statewide water and agricultural production model (SWAP) (Appendix A). Department of Agricultural and Resource Economics, University of California, Davis, California, USA. Available at http://calvin.ucdavis.edu (accessed September 2013).

Iglesias, E., and M. Blanco. 2008. New directions in water resources management: The role of water pricing policies. Water Resources Research doi:10.1029/2006WR005708.

Iglesias, A., S. Quiroga, M. Moneo, and L. Garrote. 2012. From climate change impacts to the development of adaptation strategies: Challenges for agriculture in Europe. Climatic Change 112:143-168.

INE. 2007. Censo Agropecuario y Forestal. Instituto Nacional de Estadísticas (INE), Santiago, Chile.

IPCC. 2000. Emissions scenarios. In Nakicenovic, N., and R. Swart (eds.) Intergovernmental Panel on Climate Change (IPCC), Geneva, Switzerland.

Kan, I., D. Haim, M. Rapaport-Rom, and M. Shechter. 2009. Environmental amenities and optimal agricultural land use: The case of Israel. Ecological Economics 68:1893-1898.

Massey, E., and D. Huitema. 2013. The emergence of climate change adaptation as a policy field: The case of England. Regional Environmental Change 13:341-352.

Mattas, K., F. Arfini, P. Midmore, M. Schmitz, and Y. Surry. 2011. CAP's impacts on regional employment: A multi-modelling cross country approach. p. 10-11. In C. Moreddu (ed.) Proceedings of the OECD Workshop. March 2010. Organisation for Economic Co-operation and Development (OECD), Paris, France.

Medellín-Azuara, J., J. Harou, and R. Howitt. 2009. Estimating economic value of agricultural water under changing conditions and the effects of spatial aggregation. Science of the Total Environment 408:5639-5648.

Medellín-Azuara, J., R.E. Howitt, D.J. MacEwan, and J.R. Lund. 2011. Economic impacts of climate-related changes to California agriculture. Climatic Change 109:387-405.

Mendelsohn, R., W. Nordhaus, and D. Shaw. 1994. The impact of global warming on agriculture: A Ricardian analysis. American Economic Review 84:753-771

MMA. 2013. Plan de adaptación al cambio climático del sector agropecuario. Ministerio del Medio Ambiente (MMA), Santiago, Chile. Available at http://www.mma.gob.cl/1304/articles-55879_ InstrumentoFinalCC_Silvoagropecuario.pdf (accessed 9 July 2014).

Nelson, G.C., M.V. Rosegrant, M.W. Palazzo, A. Gray, I. Ingersoll, C. Robertson, et al. 2010. Food security, farming, and climate change to 2050: Scenarios, results, policy options. International Food Policy Research Institute (IFPRI), Washington, D.C., USA.

Nelson, G.C., H. Valin, R.D. Sands, P. Havlík, H. Ahammad, D. Deryng, et al. 2013. Climate change effects on agriculture: Economic responses to biophysical shocks. Proceedings of the National Academy of Sciences 111:3274-3279.

ODEPA. 2010. Estimación del impacto socioeconómico del cambio climático en el Sector Silvoagropecuario de Chile. Oficina de Estudios y Políticas Agrarias (ODEPA), Santiago, Chile. Available at http://www.odepa.cl/wp-content/files_ $\mathrm{mf} / 1369774423$ Impacto_socioeconomico_cambio_climatico_ sector_silvoagropecuario.pdf (accessed 9 July 2012).

Quiroz, J., R. Labán, y F. Larraín. 1995. El sector agrícola y agroindustrial frente a Nafta y Mercosur. 149 p. Sociedad Nacional de Agricultura, Santiago, Chile.

Santibáñez, F. 2001. El modelado del crecimiento, desarrollo y producción del maíz sobre bases ecofisiológicas mediante el modelo SIMPROC. Revista Argentina de Agrometeorología $1(1): 7-16$ 
Santibáñez, F., P. Santibáñez, R. Cabrera, L. Solís, M. Quiroz, y J. Hernández. 2008. Capítulo I. Resumen Ejecutivo. Impactos productivos en el sector silvoagropecuario de Chile frente a escenarios de cambio climático. In Análisis de vulnerabilidad del sector silvoagropecuario, recursos hídricos, edáficos de Chile frente a escenarios de cambio climático. Centro de Agricultura y Medioambiente (AGRIMED), Facultad de Ciencias Agronómicas, Universidad de Chile, Santiago, Chile.
Swanson, D., S. Barg, S. Tyler, H. Venema, S. Tomar, S. Bhadwal, et al. 2010. Seven tools for creating adaptive policies. Technological Forecasting and Social Change 77:924-939.

von Lampe, M., D. Willenbockel, H. Ahammad, E. Blanc, Y. Cai, K. Calvin, et al. 2014. Why do global long-term scenarios for agriculture differ? An overview of the AgMIP Global Economic Model Intercomparison. Agricultural Economics 45:3-20. 